\title{
FORMULASI SABUN CAIR PENCUCI TANGAN YANG MENGANDUNG EKSTRAK DAUN KEMANGI (Occimum basilicum L.)
}

\author{
Nurlina *), Faisal Attamimi * ${ }^{*}$, Rosvina *), Ilham Tomagola *) \\ *) Fakultas Farmasi Universitas Muslim Indonesia \\ ${ }^{* *}$ ) Fakultas Farmasi Universitas Hasanuddin \\ Email : linaadin_umi@yahoo.com
}

\begin{abstract}
A study about formulation Handwash liquid soap which contain etanol extract of occimum folium (Ocimum basilicum L.). Has been conducted. This study aims to product the stable formulation of handwash liquid soap which contain etanol extract of occimum folium (Ocimum basilicum L.). This study was conducted using three variations of viscosity agent. Then do some test with storage method with organoleptic parameters, $\mathrm{pH}$, foaming test, viscosity and type of flow, before and after imposed conditions. Organoleptic test result showed theres no change at II and III, test showed that is stable because still at soap $\mathrm{pH}$ before and after imposed condition. Statistical analysis of viscosity test showed there is difference for each formula before and after storage condition. Yield value showed difference yield value before and after strorage condition and at formula there no difference. At rheogram curve theres coincides at formula III before and after imposed condition. For foaming test, three formula is stable because theres have a good foam. The conclusion is the stable handwash liquid soap is formula III.
\end{abstract}

Key words : Formulation, Handwash Liquid Soap, Occimum folium

\section{PENDAHULUAN}

Salah satu tanaman yang biasa dipergunakan sebagai obat atau produk topikal oleh masyarakat ialah kemangi (Ocimum basilicum.L). Kemangi merupakan tanaman yang dapat ditemukan dipinggir jalan yang dapat menghambat penyebaran jamur, adapun minyak yang dihasilkan dari kemangi dapat digunakan melawan bakteri dan komponen kimia dari kemangi yang berperan dalam anti bakterial yaitu minyak atsiri di mana komponennya terdiri dari eugenol, $\alpha$ pinen, $\beta$ pinen, sabinem, mirsen, limonen, 1,8 sineol, geraniol, $Z-\beta$ osimen, metileugenol, a bisabolol dan lainnya, Komponen kimia ini mampu menghambat pertumbuhan bakteri seperti : Staphylococcus aureus, Escherichia coli, Proteus vulgaris, Pseudomonas aeruginosa, Bacilus cereus, Pseudomonas fluorescens, Streptococcus alfa, dan Bacillus 
subtilis, Mycobacterium tuberculosis, Klebsiella, Proteus, Salmonella typhi, Shigella, Vibrio cholera, Neisseria gonorrhea, dan jamur seperti: Aspergillus flavus, Candida albicans, Rhizopus stolinifera.( Afini,2010)

Berdasarkan penelitian sebelumnya yang telah dilakukan oleh Ahmad (2006), yang memformulasi salep antiseptik dari ekstrak etanol daun kemangi (Ocimum basilicum.L) dengan menggunakan konsentrasi ekstrak yaitu $6 \%$, $8 \%$, dan $10 \%$, sebelumnya dilakukan orientasi daya hambat ekstrak terhadap pertumbuhan mikroorganisme, dan diperoleh pada konsentrasi $10 \%$ memiliki diameter zona hambat yang paling besar dibandingkan dengan konsentrasi $6 \%$, dan $8 \%$. Setelah itu dilanjutkan dengan memformulasi sediaan salep antiseptik, kemudian dilakukan kembali pengujian efektivitas sediaan, dimana pada konsentrasi 10\% menunjukan kemampuan daya hambat yang baik terhadap bakteri Staphylococcus aureus serta mampu menghambat beberapa bakeri uji lainnya yang ada pada kulit, khususnya bakteri yang banyak ditemukan pada tangan. Sehingga daun kemangi dibuat dalam bentuk sediaan sabun cair pencuci tangan yang berguna sebagai antiseptik.
Sabun cuci tangan dapat berupa sediaan losio atau gel, losio dapat berupa emulsi maupun larutan.

Sabun cuci tangan yang berupa larutan lebih disukai karena penampilannya yang lebih menarik. Sabun cair pencuci tangan yang mengandung ekstrak etanol daun kemangi (Ocimum basilicumL) diformulasi kandengan menvariasikan konsentrasi carbopol sebagai pengental untuk menghasilkan formulasi yang memiliki kestabilan yang optimal.

\section{METODOLOGI PENELITIAN}

Jenis dan Desain Penelitian

Jenis penelitian ini dilakukan secara eksperimental, yang merupakan penelitian laboratorium dengan menggunakan rancangan eksperimental sederhana.

\section{Waktu dan Tempat penelitian}

Penelitian dilaksanakan pada bulan Maret 2012 sampai selesai, Laboratorium Farmaseutika Fakultas Farmasi Universitas Muslim Indonesia.

\section{Alat dan Bahan Penelitian}

Alat yang digunakan yaitu batang pengaduk, botol plastik, cawan porselin, gelas erlemeyer, gelas piala $50 \mathrm{ml}, 100 \mathrm{ml}, 250 \mathrm{ml}$ (Pyrex), gelas ukur $25 \mathrm{ml}, 50 \mathrm{ml}, 100 \mathrm{ml}$ (Pyrex), 
Lumpang dan alu, kertas timbang, Penangas air, pipet volume (Pyrex), pipet tetes, sendok tanduk, timbangan analitik (chyo), thermometer, dan viscometer Brookfield.

Bahan yang digunakan yaitu: aquadest, asam sitrat, carbopol, dinatrium EDTA, ekstrak etanol daun kemangi (Ocimum basilicum.L), metil paraben, gliserin, natrium lauril sulfat dan trietanolamin.

\section{Pengumpulan dan analisis data}

\section{Pengambilan dan pengolahan sampel}

Sampel daun kemangi diambil dikota Pangkep,pengambilan sampel dilakukan dengan memetik daun segar, pada jam 10.00-12.00, sampel yang telah dikumpulkan dicuci bersih dan di sortasi basah. Sampel kemudian dikeringkan dengan cara diangin-anginkan pada tempat yang tidak terkena sinar matahari langsung hingga kadar air berkurang.

Ekstraksi sampel secara maserasi.

Simplisia ditimbang dan dimasukkan kedalam wadah ditambahkan cairan penyari etanol $70 \%$ pada simplisia. Wadah yang berisi sampel disimpan selama 5 hari dan sesering mungkin diaduk setelah itu disaring dan filtrate yang diperoleh dikumpulkan dan diuapkan dengan cara diangin-anginkan dengan kipas angin hingga diperoleh ekstrak etanol yang kental.

\section{Formula sabun cair pencuci tangan.}

Dirancang formula sediaan sabun cair pencuci tangan di formulasi dari aquadest (pelarut), asam sitrat (sebagai penetral), carbopol (pengental), dinatrium EDTA (sebagai pengkhelat), ekstrak etanol daun kemangi (Ocimum basilicum.L) (sebagai zat aktif), metil paraben (pengawet), gliserin (sebagai emollient), natrium lauril sulfat (sebagai detergen) dan trietanolamin (pembentuk sabun).

\section{Evaluasi kestabilan larutan}

Evaluasi kestabilan larutan meliputi: pemeriksaan organoleptis, penentuan viskositas sediaan, penentuan tipe aliran, penentuan $\mathrm{pH}$ ,uji kejernihan, uji busa.

\section{HASIL PENELITIAN}

Dari hasil penelitian formulasi sabun cair pencuci tangan yang mengandung ekstrak etanol daun kemangi (Ocimum basilicumL.) diperoleh hasil sebagai berikut : 
Tabel 1. Hasil pengamatan organoleptis sebelum dan sesudah penyimpanan dipercepat.

\begin{tabular}{|c|c|c|c|}
\hline \multirow{2}{*}{ Emulgator } & \multirow{2}{*}{$\begin{array}{c}\text { Jenis } \\
\text { pemeriksaan }\end{array}$} & \multicolumn{2}{|c|}{ Kondisi } \\
\hline & & Sebelum & Sesudah \\
\hline \multirow{3}{*}{$\begin{array}{c}\text { Formula I } \\
\text { Carbopol 1\% }\end{array}$} & Bau & Khas & Khas \\
\hline & Warna & Hijau pekat & Hijau pekat \\
\hline & Konsistensi & Kental, jernih & Kental, jernih \\
\hline \multirow{3}{*}{$\begin{array}{c}\text { Formula II } \\
\text { Carbopol } 2 \%\end{array}$} & $\mathrm{Bau}$ & Khas & Khas \\
\hline & Warna & Hijau pekat & Hijau pekat \\
\hline & Konsistensi & Sangat kental jernih & Sangat Kental jernih \\
\hline \multirow{3}{*}{$\begin{array}{c}\text { Formula III } \\
\text { Carbopol } 3 \%\end{array}$} & $\mathrm{Bau}$ & Khas & Khas \\
\hline & Warna & Hijau pekat & Hijau pekat \\
\hline & Konsistensi & Sangat kental jernih & Sangat kental jernih \\
\hline
\end{tabular}

Tabel 2. Hasil pengukuran $\mathrm{pH}$ pada sabun cair dengan variasi bahan pengental karbopol menggunakan $\mathrm{pH}$ meter

\begin{tabular}{ccccc}
\hline Kondisi & Replikasi & Formula I & Formula II & Formula III \\
\hline \multirow{2}{*}{ Sebelum } & 1 & 7,01 & 6,50 & 6,95 \\
& 2 & 6,98 & 6,17 & 6,89 \\
& 3 & 6,96 & 6,15 & 6,68 \\
\hline Rata-rata & & 6,98 & 6,27 & 6,84 \\
\hline \multirow{2}{*}{ Sesudah } & 1 & 6,55 & 6,10 & 6,90 \\
& 2 & 6,52 & 6,07 & 6,89 \\
Rata-rata & 3 & 6,52 & 6,05 & 6,60 \\
\hline
\end{tabular}

Tabel 3. Hasil pengukuran uji busa pada sediaan sabun cair sebelum dan sesudah penyimpanan dipercepat

\begin{tabular}{cccc}
\hline \multirow{2}{*}{ Kondisi } & \multicolumn{3}{c}{ Formula } \\
\cline { 2 - 4 } & F I & F II & F III \\
\hline Sebelum & + & + & + \\
Setelah & + & + & + \\
\hline
\end{tabular}

Keterangan : $(+)=$ Berbusa $\quad(-)=$ Tidak berbusa

Tabel 5. Hasil pengukuran viskositas pada sabun cair ekstrak daun kemangi (Occimum basilicum L.) dengan variasi bahan pengental karbopol menggunakan Viskometer Brookfield pada kecepatan 50 rpm dengan menggunakan spindel nomor 63

\begin{tabular}{|c|c|c|c|}
\hline Kondisi & $\begin{array}{c}\text { Formula F I } \\
\left(\text { dyne } \mathrm{cm}^{-2} \mathrm{dtk}^{-1}\right)\end{array}$ & 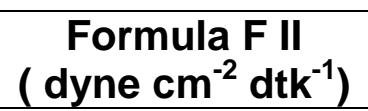 & $\begin{array}{c}\text { Formula F III } \\
\left(\text { dyne } \mathrm{cm}^{-2} \text { dtk }^{-1}\right)\end{array}$ \\
\hline B1 & 39,5667 & 60,8333 & 116,8 \\
\hline B2 & 79,1333 & 82,9333 & 117,033 \\
\hline
\end{tabular}

Keterangan : Formula B1 = Sebelum, Formula B2 $=$ Sesudah 
Tabel 6. Tipe aliran yang terbentuk pada sedian sabun cair yang mengandung ekstrak daun kemangi (Occimum basilicum .L) memiliki nilai yield sebelum dan sesudah penyimpanan dipercepat.

\begin{tabular}{|c|c|c|c|}
\hline Kondisi & $\begin{array}{c}\text { Formula F I } \\
\left(\text { dyne } \mathrm{cm}^{-2} \mathrm{dtk}^{-1}\right)\end{array}$ & $\begin{array}{c}\text { Formula F II } \\
\left(\text { dyne } \mathrm{cm}^{-2} \mathrm{dtk}^{-1}\right)\end{array}$ & $\begin{array}{c}\text { Formula F III } \\
\left(\text { dyne } \mathrm{cm}^{-2} \mathrm{dtk}^{-1}\right)\end{array}$ \\
\hline$B$ & 6.692982294 & 8.356950199 & 18.17063406 \\
\hline B2 & 10.50501485 & 11.28981574 & 23.03277776 \\
\hline
\end{tabular}

Keterangan : Formula B1 $=$ Sebelum, Formula $B 2=$ Sesudah

\section{PEMBAHASAN}

Pada penelitian ini dibuat sediaan sabun pencuci tangan dari ekstrak daun kemangi (Occimum basilicum L.), ini dibuat dengan cara maserasi dengan menggunakan pelarut etanol $70 \%$, setelah itu diuapkan untuk mendapatkan ekstrak kental.

Sediaan yang dibuat dalam bentuk sabun cair pencuci tangan ini dimana memiliki banyak keuntungan seperti kejernihan dari sedian sabun cair ini dapat meningkatkan nilai estetika pada pengguna, tingkat kepercayaan pengguna yang sangat besar terhadap sediaan sabun dalam bentuk cair dibandingkan sabun padatan tentang kebersihan, dan kenyamanan penggunaannya lebih terjamin, dapat menghilangkan bakteri atau kuman yang melekat pada tangan dimana penggunaan dengan penggosokan tangan selama 10-15 detik dengan penggunaan air mengalir sangat membantu dalam menghilangkan kuman pada tangan. Selain itu bahan-bahan dan zat aktif untuk pembuatan sabun cair pencuci tangan pada penelitian ini relatif lebih murah, selain itu dapat melestarikan dan memanfaatkan sumber daya alam disekitar yang dapat dijangkau oleh masyarakat pada umumnya.

Ekstrak etanol daun kemangi (Occimum basilicum L.) yang digunakan pada sediaan sabun cair pencuci tangan adalah 10\%, dasar pemilihan konsentrasi ini didasarkan pada hasil penelitian sebelumnya yang dilakukan oleh Ahmad (2006) yang memformulasi sediaan salep kulit dari ekstrak daun kemangi $6 \%$, $8 \%$, dan $10 \%$, dimana hasil uji efektivitas sediaan dengan metode replikasi menunjukan adanya daya antiseptik sediaan dengan kadar 10\%, mampu menghambat mikroorgaanisme pada tangan. Hal inilah yang mendasari pemilihan konsentrasi ekstrak etanol daun kemangi (Occimum basilicum L.) untuk memformulasi sediaan sabun 
cair pencuci tangan yang stabil dan efektif. Sabun cuci tangan dapat berupa sediaan losio atau gel, losio dapat berupa emulsi maupun larutan.Sabun cair cuci tangan yang berupa larutan lebih disukai karena penampilannya yang lebih menarik.

Selain penggunaan ekstrak etanol daun kemangi (Occimum basilicum L.) sebagai zat aktif, digunakan juga carbopol sebagai pengental, dengan variasi konsentrrasi $1 \%$, $1,5 \%$, dan $2 \%$. Dasar pemilihan bahan pengental dan konsentrasi yaitu carbopol mempunyai kegunaan sebagai pengental untuk larutan topikal, dan konsentrasi carbopol untuk topikal $1 \%$ sampai $2 \%$. Bahan lain yang digunakan dalam formula yaitu asam sitrat (sebagai penetral), dinatrium EDTA (sebagai pengkhelat), metil paraben (pengawet), gliserin (sebagai emollient), natrium lauril sulfat (sebagai detergen), trietanolamin (pembentuk sabun) dan aquadest (pelarut).

Pengujian kestabilan ketiga jenis formula dengan variasi konsentrasi pengental carbopol, dilakukan dengan metode kondisi dipaksakan (stress condition) dengan penyimpanan pada suhu $5^{\circ} \mathrm{C}$ dan $35^{\circ}$ selama 10 siklus, masing-masing siklus berdurasi 12 jam. Tujuan dilakukannya kondisi dipaksakan adalah untuk mempercepat proses peruraian dari bahan-bahan dan untuk mempersingkat waktu pengujian. Pengujian ini dilakukan dengan beberapa parameter,yaitu :

Pemeriksaan organoleptis menunjukkan bahwa untuk formula sabun cair pencuci tangan pada formula I, II, dan III, pada kondisi sebelum dan setelah dipaksakan tidak mengalami perubahan warna, bau, dan konsistensi, namun terlihat perbedaan konsistensi pada Formula I, II, dan Formula III, Formula dengan konsentrasi carbopol $2 \%$ konsistensinya lebih kental.

Pengukuran $\mathrm{pH}$, dilakukan dengan menggunakan $\mathrm{pH}$ meter. Hasil rata-rata pengukuran $\mathrm{pH}$ yang dilakukan sebelum dan sesudah kondisi dipaksakan tidak terlalu berbeda jauh, dan tetap berada pada range 6-7 $\mathrm{pH}$ sabun hal ini mengindikasikan bahwa $\mathrm{pH}$ sediaan sabun cair pencuci tangan stabil dalam penyimpanan.

Uji busa, pengujian ini dilakukan untuk melihat apakah sediaan sabun cair dengan variasi pengental carbopol dapat berbusa pada saat digunakan. Pengujian ini dilakukan dengan mengambil sejumlah sabun cair pada sediaan letakkan ditelapak tangan, 
kemudian ditambah dengan sedikit air dan gosok kedua telapak tangan secara bersamaan hingga berbusa. Ketiga formula sabun cair ekstrak etanol daun kemangi (Occimum basilicum.L) tersebut memberikan hasil formulasi yang dapat berbusa.

Pengukuran

viskositas,

dilakukan dengan menggunakan viskometer brookfield dengan spindel nomor 63. Hasil analisis statistik dengan metode rancangan acak kelompok menunjukan adanya perbedaan yang sangat nyata diantara ketiga formula maupun pada kondisi penyimpanannya. Sehingga dilakukan uji lanjutan. Dan uji lanjutan yang digunakan adalah uji BNT (Beda Nyata Terdekat). Hal ini dikarenakan nilai koefisien keseragaman yang diperoleh diatas $10 \%$ yaitu $11,0331 \%$. Berdasarkan hasil uji lanjutan diperoleh formula sabun cair yang mempunyai kestabilan yang baik adalah formula III, karena tidak ada perbedaan viskositas yang terjadi selama penyimpanan dipercepat.

Tipe aliran suatu sediaan ditentukan berdasarkan ada atau tidak adanya nilai yield. Nilai yield merupakan nilai yang harus dilampaui oleh suatu sediaan agar bisa mengalir melewati wadahnya. Nilai yield merupakan satu parameter dari beberapa parameter yang mempengaruhi kestabilan suatu sediaan. Nilai yield lebih banyak berhubungan dengan apllikasi dari sediaan. Hubungannya dengan kestabilan terutama hanya dengan tipe aliran yang terbentuk, dimana apabila terjadi perubahan nilai yield akan mengakibatkan juga berubahnya aliran suatu sediaan. Dan ini berarti mengindikasikan terjadinya perubahan pada tipe sediaan. Perubahan tipe aliran sediaan biasanya menandakan terjadinya ketidakstabilan. Hasil analisis statistik dengan metode rancangan acak kelompok menunjukan bahwa formula yang optimum yaitu formula III dimana tidak terjadi perubahan yang nyata sebelum dan sesudah penyimpanan dipercepat.

Dari data rheogram yang dibuat gambar rheogram, terlihat bahwa dari ketiga formula sabun cair yang mempunyai jarak pemisahan rheogram tidak terlalu jauh adalah formula III. Pemisahan ini mengindikasikan perubahan nilai yield pada kondisi sebelum dan sesudah penyimpanan dipaksakan. Selain itu, rheogram juga memperlihatkan aliran yang dimiliki oleh suatu sediaan. Dan pada reogram hubungan antara shearing stress (tekanan geser) dan rate of shear (kecepatan geser ), maka 
aliran yang diperoleh adalah aliran plastis dimana semua kurva formula tidak melalui sumbu tekanan geser.

\section{KESIMPULAN}

Berdasarkan hasil dari parameter penelitian, disimpulkan bahwa formula III sabun cair pencuci tangan yang mengandung ekstrak etanol daun kemangi (Occimum basilicum.L) dengan konsentrasi pengental carbopol $2 \%$ yang menunjukan kestabilan fisik yang paling optimal.

\section{DAFTAR PUSTAKA}

Ahmad, H. , 2007. Pengaruh Tipe Basis Salep Terhadap Aktivitas Antimikroba Salep Ekstrak Etanol Daun Kemangi (Ocimum basilicum L) pada staphylococcus aureus dan candida albicans, Universitas Muslim Indonesia, Makassar.

Afini,2010.Uji aktivitas Daya anti bakteri Daun kemangi (Ocimum basilicum L.)Terhadap bakteri Eschercia coli dan Staphylococcus aureus secara in vitro, FK. Universitas Muhammadiyah.

Banker and Rhodes,C.T York, 1979. Modern Pharmaceutics, volume 7, Marcell Dekker, Inc,New York, Bassel.

Dian anggriani, 2002. Ekstraksi dan pemanfaatan minyak daun kemangi sebagai pewangi pada sabun cuci tangan cair. IPB,Bogor.
Direktorat Jenderal Pengawasan Obat dan Makanan 1986.Sediaan Galenik. Jakarta.

Ditjen POM.,1979, Farmakope Indonesia, Edisi III, Depertemen Kesehatan Republik Indonesia.

Ditjen POM.,1979, Farmakope Indonesia, Edisi IV, Depertemen Kesehatan Republik Indonesia.

Garrity, G. M., Bell, J.A., dan Lilbum, T.G., 2004.Taxonomic Outline of The Prokaryotes Bergey's Manual of Systematic Bacteriology, 2th Edition, Springer, New York Berlin Hendelberg, United States of America.

Gennaro,A.R.,2000, Rhemington's Pharmaceutical Sciences, $20^{\text {th }}$ edition, Mack Publishing Company, Easton, Pennsyvania.

Gunawan,..2002.Ramuan Tradisional untuk Keharmonisan Suami istri.Penebar Swadaya, Jakarta.

Hariana.A, 2004.Tumbuhan obat \& Khasiatnya Seri 1. Penebar Swadaya, Jakarta.

Jenkins,G., 1957. Scoville's The Art Of Compunding, Ninth Edition.The Blackiston Division, Mc Graww Hill Book,Company.

Kibbe,A.H., 2000, Handbook Of Pharmaceutical Excipient, Three Edition, American Pharmaceutical Press.

Lachman,L.dkk, 1986, Terjemahan Teori dan Praktek Farmasi Industri, Edisi II, Universitas Indonesia Press. 
Martin,A., 1980, Terjemahan DasarDasar Farmasi Fisika dalam IImu Farmaseutika, Edisi II, Penerbit Universitas Indonesia, Jakarta.

Pelczar,M.J.,2005. Dasar-dasar Mikrobiologi, Penerjemah R.S.Hadiotomo dkk, Ul-Press, Jakarta.

Staff ,M.C. 2009. Hand Washing :An Easy Way To Prevent Infection. www.MayoClinik.com

Snyder ,O.P. 1999. A "Safe Hands" Hand Wash Program For Retail Food Operation : A Technica ireview www. hitm.com/ Documents/Hand Wash-FL99 $\underline{\text { html }}$

Sprowls,J.B, 1960, American Pharmacy Text Book Of
Pharmaceutical

Principles, Proses and Preparation, Fifth Edition, J. B Lipincott Company, Philladelphia.

Sprowl,J.B, 1970, Prescription Pharmacy, Second Edition, J.B.Lipincott Company Montreal, Philadelpia

Tjitrosoepomo,G,1994, Taksonomi Tumbuhan dan Obat-Obatan, Gadjah Mada University Press, Yogyakarta.

Tranggono, J.R., 2007, Pegangan IImu Pengetahuan Kosmetik, Penerbit PT. Gramedia Pustaka Utama, Jakarta.

Wasitaatmadja., M., S., $\quad$ 1997, Penuntun IImu Kosmetik Medik, Penerbit, Universitas Indonesia. 